\title{
The Lifeline of Chromos: Translation and Felipe Alfau
}

\author{
Regina Galasso \\ BMCC, The City University of New York
}

I. Introduction

Eduardo Lago (Madrid, 1954) surprised the literary world in early 2006 when he won Spain's Premio Nadal for his first novel Llámame Brooklyn. Although he had previously published a few books, he was better known as a Spanish-born, New York-based professor and literary translator. After receiving the prestigious award, in interviews, he was repeatedly asked to affiliate himself with either US or Spanish literature: "Do you feel closer to American literature than to Spanish literature?” (Rodríguez Martorell 20); “Se siente quizá un escritor más americano que español?” (Azancot 7). These questions demonstrate the immediate need to compartmentalize Lago and his writing, and the challenges of such a task when an author deviates from limited understandings of national literatures, based on monolingual and geographically restricted guidelines. Llámame Brooklyn, a novel that draws from US and Spanish literary traditions, written in Spanish, perplexes established categories, jeopardizing its inclusion in them, and, what is more, threatens its survival in literary studies. ${ }^{1}$

Lago is a literary descendent of another Spanish-born writer who spent most of his life in New York: Felipe Alfau (1902-99). Lago beholds Alfau as his "literary "patron saint"” (Rodríguez Martorell, "Hispanic" 5). Alfau, too, amazed the literary world in 1990 when his novel Chromos, approximately fifty years after its creation, was published by Dalkey Press and consequently nominated for the National Book Award. Chromos, the second of Alfau's two novels, was praised for its avant-garde techniques, which were later credited to a generation after him which includes postmodern writers like John Barth (1930) and Thomas Pynchon (1937). Critics also placed his work among the ranks of some of the most influential writers of the twentieth century like Vladimir Nabokov (1899-1977) and Italo Calvino (1923-85). Alfau's influence on Lago's work is apparent in numerous ways, but the most notable similarity is in terms of the structure. Lago's novel, as Fernando Valls describes it, is "una novela collage, un género de géneros, a la manera del tejido textual que muestra una historia,

\footnotetext{
${ }^{1}$ Debra Castillo expresses similar concerns about other authors from Spain in her article "Latina or Americaniard?" She begins her inquiry by stating: "Authors, texts, and ideas have always moved across international borders; yet to the degree that they confound monolingual and nationally-based literary projects, such as crossings and mediations have been insufficiently studied even by an academic audience that prides itself on its border-crossing analytic abilities" (47). She is concerned with Spanish-born authors who write in the US.
} 
TranscUlturAl, vol.1,3 (2010), 43-55.

http://ejournals.library.ualberta.ca/index.php/TC

utilizando piezas de muy diverso calado y distinta procedencia" (142). ${ }^{2}$ Both Chromos and Llámame Brooklyn include the creation of a novel within a novel thus nourishing a segmented structure.

Among the parallels of the literary profiles of Lago and Alfau, there are stark differences, chiefly involving language. Although Lago has spent many years outside of Spain, dramatic alterations do not mark his written Spanish. On the contrary, Lago confesses that when he goes to Spain his "accent seems distorted," and that he sometimes makes lexical choices associated with Mexican or Chilean Spanish (Rodríguez Martorell, “Ode”). Alfau’s situation is all the more complicated since his novels are in English, not his mother tongue, leading to significant critical inquiry. ${ }^{3}$ However, his linguistic decision alone is not responsible for this attention, but rather the characteristics of Alfau's particular language. The translator Gregory Rabassa comments that "the very language of [Alfau's] narration is perfectly good English, and yet it is not English. Nor is it Spanish either in a free or in a literal translation" (224). Alfau describes his own prose as "half English and half my own creation, the result of an immigrant experience," or simply "Iberian English" (Stavans, "Anonymity" 151). Alfau's English is special because it relies on knowledge of both Spanish and English without being dependent on code-switching. ${ }^{4}$

As Chromos's first-person narrator directly addresses the reader--"I take this opportunity to advise all my countrymen" (11)--"Iberian English” is appropriate since the novel's ideal audience consists of other New York residents from Spain. Although the text is aware of a bilingual reader, why doesn't the language resort to more instances of code-switching, or the

\footnotetext{
${ }^{2}$ Valls does not explicitly state Lago's indebtedness to Alfau in his review of Llámame Brooklyn. In fact, Alfau's descriptions of how he wrote Chromos echo Valls's description of Lago's novel: "In the office between one document and another, I would write a paragraph or two. I then pasted together the whole book, as in a collage" (Stavans, "Anonymity" 151).

3 Ilan Stavans mentions other "writers who have mastered a second language and used it to write their oeuvre: Joseph Conrad, Vladimir Nabokov, Joseph Brodsky, and Jerzy Kosinski” (“Anonymity” 149). Alfau's situation also presents an example of the multilingual dimensions of Hispanic literature. For cases of Spanish-American writers who write in languages other than Spanish see Unhomely Rooms: Foreign Tongues and Spanish-American Literature by Roberto Ignacio Díaz, in which he "reconfigure[s] SpanishAmerican literature as an entity with no fixed linguistic midpoint" (26). Among the writers he studies are Comtesse Merline, W.H. Hudson, and Carlos Fuentes.

${ }^{4}$ Although there is diversity among the usages of code-switching, it is often associated with Latino writing in the US. See Lourdes Torres's article "In the Contact Zone: Code-switching Strategies by Latino/a Writers," for examples of texts and authors that incorporate code-switching into their writing. It is curious to point out that Chromos was published at the dawn of the decade in which Latino literature was "finally recognized by mainstream publishers as a legitimate, indeed integral, part of American letters" as explained by Margo Gutiérrez.
} 
TranscUlturAl, vol.1,3 (2010), 43-55.

http://ejournals.library.ualberta.ca/index.php/TC

alteration of Spanish and English, in the text? Alfau was not a professional writer; he earned a living as a translator at Morgan Bank in New York. While it could be argued that the practice of creative writing presented Alfau with the opportunity to compensate for the monotonous work of a bank translator (Shapiro 199), he did not completely abandon ideas about translation in his literature.

Throughout Chromos the self-references are striking. First, the narrator is also a professional translator who shies away from any commitment to translation work beyond his usual responsibilities: "Translating being my business and means of livelihood, I am naturally disinclined to take on extra work, particularly of doubtful remuneration" (51). The narrator sets strict divisions between translation as a profession and as a leisure activity, just as Alfau neglected to think of himself as a writer or to read major authors (Stavans, "Anonymity" 152). However, it is ironic that both Alfau and Chromos's narrator successfully complete the tasks that they resist. Rabassa further comments that Chromos "is a remarkable book, not only for what it says, but also for what it is struggling to say, often with strangely successful insights" (224). Additionally, Albert Mobilio, in his review of the novel for Village Voice, describes Chromos as "an extended mediation on exile, especially the linguistic limbo that divides the new language from the old" (18). Both statements hint at the treatment of language ingrained in the novel, but do not elaborate on how Alfau's literature uses language itself not only as a means but also as a message.

There is something more to the language of Chromos that reaches beyond the influence of Spanish on English. Alfau's commitment to translation is, I would argue, responsible for his "Iberian English." Translation is not only a purely linguistic question, but also a conceptual one as questions of translation permeate every level of Chromos's patchwork narrative. In this essay, I examine the different ways in which Chromos, as an original version of a text, incorporates translation techniques and demonstrates a reliance on translation for its unique language. Further, I discuss how the role of the translator sustains the novel. I propose that Chromos is not only outstanding for its structural innovations, but also for its multifaceted exploration of translation in addressing the condition of a Spanish author writing from New York. 
TranscUlturAl, vol.1,3 (2010), 43-55.

\section{Translation Only}

The question to write in Spanish or English not only applies to Alfau, but also to his characters. Early in Chromos the writer Garcia reads to the first-person narrator a portion of the novel that he is writing about a family in Spain and asks for his opinion:

"Well?"

"Oh, it is fine, fine-the only thing: to come all the way to New York to write a novelabout a family in Spain. ..."

"I did not come here to write it, you ought to know that. I am here and I happened to think of writing it. That's all."

"But who is going to read it? Unless it is for your own satisfaction or records...."

"I am not thinking of publishing it in Spanish here. I have in mind one or two publishing houses in Latin America, or perhaps even Spain, although I would rather-but what I was really thinking is that you might help me with the English translation. I will show you some other parts I have already written out, even if they still need a little polishing."

"Well, I don't know about that. My English is not so good." (34)

Their conversation is concerned with the extra-textual situations, practical questions surrounding a text that authors consider: setting, audience, publisher, and language. ${ }^{5}$ Being that Spanish is not recognized as a literary language of New York, if Garcia chooses to write in Spanish, he must look beyond New York in order to publish his work; and if he chooses to publish it locally, he must translate it into English. ${ }^{6}$ Either way, the novel undergoes a detachment from its source: from its original language or its birthplace.

Garcia's novel as a fictional object written by an imaginary character cannot be detached from Chromos as a real text. Throughout Chromos, since Garcia's novel is unfinished, he and the narrator take the opportunity to discuss the plot as well as questions of language, especially aspects that will be of concern for its English translation. Garcia and the narrator begin a conversation about language choice, but do not arrive at any definitive conclusion about which option would be best given the extra-textual circumstances. Instead, Garcia is convinced that the process of translation will accompany the creation of the original version of the text.

\footnotetext{
${ }^{5}$ The limitations of a single-language/single-national literary history paradigm do not accommodate certain texts, or aspects of certain texts. In their discussions of literary history, Mario Valdés and Linda Hutcheon acknowledge that "literature does not exist in isolation from the culture in which it is 'experienced' - that is, the culture in which it is both produced and received" (12). The narrator and Garcia's conversation exhibits these same concerns.

${ }^{6}$ It is of interest to note that Alfau "wholeheartedly hated the New York literary world," according to Chandler Brossard (195).
} 
Garcia's preoccupations not only come in the form of how a specific word will translate, but also how an English-speaking audience will receive the plot. ${ }^{7}$ Included in Garcia's novel is a passage about Julieta Sandoval and her special maid who discussed "forbidden subjects with her mistress" (61). At this point, the narrator discovers "a pornographic turn" in Garcia's text, which he finds "uncalled-for" and "irrelevant," and warns him "if I had anything to do with the translation, I would not tolerate any more of such passages which could only offend the ears of the English reader" (62). However, the out of place section of the novel is not delivered as part of Chromos: the text has already been censored. The narrator's plans for the English translation are already carried out in what is deemed the original version. The narrator's reaction takes into account cultural aspects, or what is culturally appropriate for a given audience.

However, the point is not to highlight cultural differences, but rather to acknowledge that this gesture suggests that the task of translating provides the opportunity for revision. It solicits the translator's input beyond questions strictly related to language, permitting the translator to also work as the co-author of the text. ${ }^{8}$ The translator, instead of holding a peripheral position with regard to the source text, has an essential relationship to it, detracting from the independence and authority of Garcia as the author. In other words, Garcia relies on the translator in order to complete his novel, therefore inverting the relationship between translator and author. In Chromos, the author does not have a text without the translator. ${ }^{9}$

Garcia's role as an author not only becomes secondary when working on his novel, but also in the creation of another story that he is writing about Julio Ramos, a Spaniard who never returns to Spain once he leaves in search of a new life in New York. This story, like

\footnotetext{
${ }^{7}$ For example with regard to cursi, the narrator comments: "The word 'cursi' is difficult to translate, its meaning almost impossible to convey with any other word, and the closest I can find to it in English is the word "corny"' (58).

${ }^{8}$ Since Chromos and Llámame Brooklyn are invested in the process of writing, both question the boundaries of authorship. With regard to Lago's work, Valls warns: "No hay que confundir, pues, la novela de Gal y Ness con la de Eduardo Lago, que la contiene. A este respecto, quizá no esté de más preguntarse sobre la autoría de esa curiosa obra cuyas peripecias compositivas también se narran en sus páginas. ¿A quién pertenece el resultado, a Gal, a Ness, o acaso a ambos?" (141).

9 In her preface of the third edition of Translation Studies, Susan Bassnett outlines the history of the discipline. She indicates that "in the new millennium translation scholarship will continue to emphasize the unequal power relationships that have characterized the translation process" (5). Chromos, written during the 1940s, deconstructs inequalities associated with the translation process by presenting neither the original as superior nor the translation as inferior. In Chromos, both depend on each other for the creation of the text.
} 
TranscUlturAl, vol.1,3 (2010), 43-55.

http://ejournals.library.ualberta.ca/index.php/TC

the one about the Spanish family, exists as an entirely different text within Chromos. As Garcia tells the narrator about his ideas, he also insists that the best way to convey this story is a "moving picture because of the more flexible technique" (51) that "could show the shifts and changes of scenery and the action much better" (81). Garcia is, once again, relying on "a lot of translating and perhaps a little collaborating" on behalf of the narrator in order to complete his new project (51). Although Garcia is an active author, working simultaneously on two projects, both will forever remain incomplete. Language and medium, as barriers for him to fully realize his projects, suggest the insecurities cast on Garcia as a writer from Spain in New York.

The collaboration between the narrator and Garcia involves an English translation of Garcia's texts; however, the texts are already in English, even though the two characters speak about their Spanish-language counterparts. A similar situation occurs in their conversations that pertain to the highest narrative level of Chromos in which the narrator also acts as a translator. For example, upon leaving the Spanish Theater and commenting on a theatrical production of Don Juan Tenorio, the narrator comments to Garcia: "If we were speaking English, I could say that the drama was not ghostly but ghastly, get it?” (48). Stating the language of a conversation is a technique employed in translation when it is necessary to emphasize the language in which a particular conversation takes place. In this sense, Chromos plays with an existence for its own characters in Spanish beyond the text itself. Thus, as Chromos refers to a source text beyond the actual novel and exemplifies a style that leaves traces of a translated work, it acts as an impersonation of a translation of an original version.

To further attest to the awareness of a Spanish version of this text, some words are in Spanish because the narrator confesses that he cannot provide an English equivalent. When describing another character, he says: "The man who had spoken the castigating line was middle-aged, very happy and antipático-I can't find another word" (129). Since Chromos's ideal reader presumably understands Spanish, the reason for which antipatico is used, followed by an apologetic explanation for its inclusion, speaks to the sensitivity for language in the text. The narrator is aware that this text should be in English, and therefore needs to justify the retreat to Spanish.

Further, the explanation is a way of establishing intimacy between the reader and the narrator. The narrator not only communicates to the reader information that does not appear in the characters' conversations, but also implies the special effort made to search for 
TranscUlturAl, vol.1,3 (2010), 43-55.

http://ejournals.library.ualberta.ca/index.php/TC

the adequate word, and to then cushion the text upon failing to do so. These strategies give the impression that Chromos is a translation. Chromos, an imitation of a translation, reveals Alfau's inability to detach his literary authorship from the craft of translation.

\section{III. "Español" $\neq$ Spanish}

The opening lines of Chromos are Alfau's most frequently quoted words: "The moment one learns English complications set in" (7). At first the statement seems general, but it is soon after established that Chromos heeds the results of the contact between Spanish and English. While Chromos comprises an amalgam of stories, the novel's overarching composition focuses on the narrator, Garcia, and a group of characters in New York who are either from Spain or hold some connection to the country. The subject of their Spanishness becomes the main focus of their discussions as they learn that in the New York context español does not equal Spanish. Spanish takes on other meanings in the city and for some, it provides a spark for constant conversation, and for the unfortunate ones, death.

The unluckiest character in the novel is Don Hilarión. "Don Hilarión was a notario, not a notary, mind you; that does not quite convey the meaning, but a notario. A notario in Spain, at least in Don Hilarión's day, was a title given to a man having achieved the summit of his career in the field of law. It was the coronation of every law student" (173). With this example the novel makes a point of cultural translation by noting the different socioeconomic implications of being a notary in New York and in Spain. However, for the non-Spanish community in New York, this difference requires an explanation.

Unable to practice his profession in New York, Don Hilarión encloses himself in his tiny office in his family's apartment. One day an insurance salesman visits him at home and upon hearing that he is a notario says: "Anybody can be one. All you have to do is pay a few dollars and you are a notary" (181). Shortly after hearing these words, Don Hilarión expires. Humor is used here, on the one hand, to address the severe consequences of a strong bond between a man and his profession, and, on the other, to call attention to the irreversible mistake that an inadequate translation can cause. The monolingual salesman is unaware of the extralinguistic measures involved in translation. In the end, a question of translation, or the failure to acknowledge the complexities of translation, causes Don Hilarión's demise. ${ }^{10}$

${ }^{10}$ Hilarious well defines this character's death. The Spanish word "hilarante" is a possible translation of hilarious, echoed in the name Don Hilarión. Since this pun speaks to readers with knowledge of both 
TranscUlturAl, vol.1,3 (2010), 43-55.

http://ejournals.library.ualberta.ca/index.php/TC

Just as the differences between notario and notary are not recognized in English-speaking New York, neither is what it means to be from Spain. The narrator says: "It seems that to be from Spain is quite a claim, but to come from Madrid is unbelievable. I have been doubted so much that now I say that I am a Latin American and save myself a good deal of trouble" (10). Once again, what appears to be a simple assertion takes on other meanings, and, moreover, with this example, reveals ambiguities that surface with regard to nationality especially among Spaniards and Latin Americans. ${ }^{11}$ The Spanish perspective, or the Spanishlanguage word for something, cannot be substituted by one single English word.

Chromos incorporates extraordinary situations and exaggerated solutions to express the dangers and dilemmas of translation, as well as wavering concepts of nationality. ${ }^{12}$ Chromos shows that being "Spanish" in New York ceases to exist as solely meaning from a specific country, and extends to anyone Spanish-speaking or seemingly Spanish-speaking. As a result, it is not a surprise that Don Pedro's favorite subject is "an obsession with the position of the Spaniard in the world, with more assurance in Spain and with more complications in foreign lands--all right, in this country" (12). Chromos argues that in New York, being a Spaniard is particularly complicated due to the fact that "Spanish" ceases to exist as it does in Spain, and reversely being outside of Spain forces one to ponder what it means to be Spanish. On the final page of the novel, the narrator explains: "In Spanish one sees and things remain unquestioned and clear. In English, one studies and uncovers meanings that one does not understand. It is then that, as I said in the beginning, complications set in" (348). Chromos attributes contact with the English language for this dilemma; however, I would also add that it is the struggles of translation, the impossible task to find exact equivalence in another language, that trigger complications.

Spanish and English, the ability to "read" Chromos in both languages adds another layer to the reader's understanding and enjoyment of the novel.

${ }^{11}$ Castillo highlights another instance of the associations between Spain and other Spanish-speaking countries in the US context. She quotes from Concha Alborg's novel Beyond: Jet-lag:

The minute we opened our mouths, we were foreigners ... Like to answer the mantra question of

"Where are you from?"

--Espain, we'd answer in chorus.

--Really? Oh! I love Mexico! (qtd. in Castillo 49)

12 María DeGuzmán provides a thorough discussion of this aspect of the novel in her book Spain's Long Shadow: The Black Legend, Off-Whiteness, and Anglo-American Empire. She studies Alfau's work with regard to the denaturalization of nationality, or the idea that "nationality as an essence or as a fixed, unitary, or 'pure' identity, like essence itself, is a construction, a fiction, a collective hallucination" (276). 
TranscUlturAl, vol.1,3 (2010), 43-55.

http://ejournals.library.ualberta.ca/index.php/TC

The peculiarities of Chromos's language and the way in which the novel plays with translation on multiple levels demonstrate Alfau's attention to this art, and also speak to the challenges this text proposes for its translation into Spanish. How would the Spanish translation deal with Chromos's special language? How would it translate the passage about the antipático? With regard to Don Hilarión's story, would the Spanish translation incorporate an explanation of notario? Would the translation require instead an explanation of notary? Alfau commented on the Spanish translation of Chromos in an interview:

When I read the lousy Spanish translation, made in Barcelona, of Chromos, I thought my message had been deformed, my intentions inverted. The translator often misunderstands a sentence. Unfortunately, the mistakes are not rare. The art of translation is difficult, to say the least. One cannot substitute one word in a language with its equivalent in another. The task is to make two cultures find a common path, a bridge. I think translators must be anthropolinguists if they want to succeed in their profession.(Stavans, "Anonymity" 150)

Alfau's comments on the Spanish translation prove his awareness of the arduous task of translation and reveal the necessity to go beyond purely linguistic measures in order to cultivate a successful translation.

Chromos presents an example of the work of an anthropolinguist when Don Pedro invents "a word of his own composition" (13): "Americaniard". "Americaniard", a combination of the words American and Spaniard, explains the condition of being a Spaniard in New York. ${ }^{13}$ The narrator explains that Don Pedro:

had begun to originally employ [the term] when referring to Spaniards in the Americas and at one time might have included Latin Americans, but he had gradually varied the meaning until at present it applied to all Spaniards in New York and then by association even to other foreigners, especially of Latin origin, in the same circumstances. (13)

In its early days, "Americaniard" had a more encompassing definition as it incorporated "Spaniards in the Americas" but later evolved into a more pointed term focusing on New York and Spaniards, and consequentially any immigrant of Latin origin to that same city. Don Pedro's definition realizes that the condition of a Spaniard in New York is unique and therefore has nothing to do with that of a Spaniard in Florida, Texas, or California. The evolution of the definition of "Americaniard" exhibits the need to address a local phenomenon.

${ }^{13}$ Several scholars have written about the space between two cultures as life-on-the-hyphen (Gustavo Pérez Firmat) or a condition (Stavans). Chromos's creativity with language assigns a linguistic invention to this state. 
TranscUlturAl, vol.1,3 (2010), 43-55.

http://ejournals.library.ualberta.ca/index.php/TC

While it could be said that an immigrant of "Latin origin" could include both Spaniards and Latin Americans, as well as Italians and French for example, the condition of the Americaniard throughout Chromos refers to Spaniards and also to any other Spanish-speaking Latins, or Latin Americans and may be even US-born Spanish-speaking citizens. ${ }^{14}$ "Americaniard" is a flexible category that defies strict national classifications. Without being one or the other, it strives to create the bridge or, in the words of Susan Elizabeth Sweeny, "seek such equilibrium," or balance that would successfully unite the two (207). ${ }^{15}$

\section{Conclusions}

"Americaniard" could arguably be a precursor of Latino as Stavans refers to Alfau as a Latino writer in his book The Hispanic Condition: Reflections on Culture \& Identity in America (175). Debra Castillo disassociates the continuity between the two terms by placing them in opposition. She notes that "Americaniard", on the one hand, "captures the ambiguity of identity," (49) but on the other hand lacks the "socio-political base" of "Latina" (57). Her suggestion, then, aims at shying away from terminology and "clutching to the idea of Latina" (57) to transform disciplinary boundaries and restrictions with regard to national literature and language. However, at the same time, I do not think that literary studies should shun the ideas behind "Americaniard" as the term is particularly appealing to those authors and texts lacking the political implications of "Latino/a", but at the same time subscribing to a non-Anglophone literary tradition of New York.

Eduardo Lago is a writer, who when pressed to classify himself as either Spanish or American, has opted for Americaniard: "Soy también uno de los americanos con un guión; un español-americano, o como el escritor Felipe Alfau lo pondría como broma, un americaniard" (Rodríguez Martorell, “Ode”). Furthermore, he has not only adverted to the term on a personal level, but has also found a place for Americaniards in his creative work. Llámame Brooklyn presents a group of writers of different backgrounds called los Incoherentes,

14 Other popular uses of the word "Latin" during the early twentieth century refer only to Latin Americans and/or Spaniards. For example, in Al Jolson's performance of the song "She's a Latin from Manhattan," the singer mesmerized by a woman he spots in New York wonders "is she from Havana or Madrid?" Not so convinced about either option, he determines "by her mañana" that she is a Latin from Manhattan.

${ }^{15}$ Interestingly, Alfau and Homi Bhabha share similar ideas about translation. Bassnett, in her overview of translation studies, explains that "Bhabha uses the term 'translation' not to describe a transaction between texts and languages but in the etymological sense of being carried across from one place to another" (6). In a similar fashion, Alfau describes the translator as being responsible for providing the passage between cultures. 
TranscUlturAl, vol.1,3 (2010), 43-55.

http://ejournals.library.ualberta.ca/index.php/TC

of which the character Alfau is a part, who unite on the Lower East Side to discuss their work. Three of the five members of los Incoberentes are referred to in the novel as Americaniards. Although the term is humorous, it does have force. Lago's use of “Americaniard" speaks not only to the successful "anthropolinguist" effort of Don Pedro as its implications reach beyond Chromos, but also to the transforming, extra-linguistic effects that translation can introduce to literary categories.

Ideas about translation and the role of the translator, as expressed by Alfau and carried out in his literature written in the 1940s, are also precursors to scholarship on translation. Overall, Chromos is the story of Americaniards living in Manhattan that would not be possible without the work of the narrator to translate his interactions with other characters along with his fellow character's creative writing. It is then not paradoxical to realize that without translation, Chromos would not exist. 
TranscUlturAl, vol.1,3 (2010), 43-55.

http://ejournals.library.ualberta.ca/index.php/TC

\section{REFERENCES}

Alfau, Felipe. Chromos. Elmwood Park, IL: Dalkey Archive, 1990.

Azancot, Nuria. "Eduardo Lago: En Llámame Brooklyn conviven Cervantes y Don DeLillo." El Cultural. 8enero 2007 < http://www.elcultural.es/HTML/20061228/Letras/Letras19412.asp >.

Bassnett, Susan. Preface. Translation Studies. By Susan Bassnett. London: Routledge, 2002. 110.

Brossard, Chandler. "Two or Three Things I Know about Him." The Review of Contemporary Fiction 13.1 (1993): 194-197.

Castillo, Debra A. "Latina or Americaniard?" Revista Canadiense de Estudios Hispánicos 30.1 (2005): 47-59.

DeGuzmán, María. Spain's Long Shadow: The Black Legend, Off-Whiteness, and Anglo-American Empire. Minneapolis: U of Minnesota P, 2005.

Díaz, Roberto Ignacio. Unhomely Rooms: Foreign Tongues in Spanish-American Literature. Lewisburg, PA: Bucknell UP, 2002.

Gutiérrez, Margo. "Latina and Latino Literature: Anthologies of the 1990s, A Selected Bibliography.” Ed. Ann Hartness. BiblioNoticias 95 (1998)

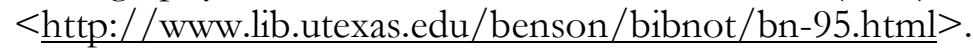

Jolson, Al. "She’s a Latin from Manhattan.” By Harry Warren. Go Into Your Dance a film by Archie Mayo. Warner Bros., 1935.

Lago, Eduardo. Llámame Brooklyn. Barcelona: Destino, 2006.

Mobilio, Albert. “Loco Heroes: Felipe Alfau's Alien Nation.” Village Voice Literary Supplement June 1990: 18.

Pérez Firmat, Gustavo. Life on the Hyphen: The Cuban-American Way. Austin: U of Texas P, 1994.

Rabassa, Gregory. "The Power of Chromos." The Review of Contemporary Fiction 13.1 (1993): 223-224.

Rodríguez Martorell, Carlos. "Eduardo Lago-An Ode to Brooklyn.” Críticas Magazine. 15 April 2006 < http://www.criticasmagazine.com/article/CA6322850.html>.

---. "Hispanic Authors Celebrate Literary Works in the Big Apple." Críticas Magazine. 15 February $2007<\underline{\text { http://www.criticasmagazine.com/article/CA6416606.html>. }}$

Shapiro, Doris. "Hidalgo Remembered."The Review of Contemporary Fiction 13.1 (1993): 198202. 
TranscUlturAl, vol.1,3 (2010), 43-55.

http://ejournals.library.ualberta.ca/index.php/TC

Stavans, Ilan. "Anonymity: An Interview with Felipe Alfau." The Review of Contemporary Fiction 13.1 (1993): 146-157.

---. The Hispanic Condition: Reflections on Culture \& Identity in America. New York: HarperPerennial, 1995.

--- and David Bellos, guest eds. The Review of Contemporary Fiction 13.1, 1993.

Torres, Lourdes. "In the Contact Zone: Code-switching Strategies by Latino/a Writers." Melus 32 (2007): 77-97.

Valdés, Mario and Linda Hutcheon. Rethinking Literary History--Comparatively. N.p.: American Council of Learned Societies, 1994.

Valls, Fernando. “Luces y sombras de Brooklyn.” Revista de Occidente 307 (2006): 139-145. 